\title{
CARP MACROPHAGES AND NEUTROPHILIC GRANULOCYTES SECRETE AN INTERLEUKIN-1-LIKE FACTOR
}

\author{
B. M. Lidy Verburg-van Kemenade, ${ }^{*}$ Franci A. A. Weyts, ${ }^{*}$ Reno Debets, $†$ and \\ Gert Flikł
}

\begin{abstract}
*Department of Experimental Animal Morphology and Cell Biology, Agricultural University, $6700 \mathrm{AH}$ Wageningen, The Netherlands; †Department of Immunology, Erasmus University, 3000 DR Rotterdam, The Netherlands; fDepartment of Animal Physiology, Catholic University, Toernooiveld, 6524 ED Nijmegen. The Netherlands
\end{abstract}

(Submitted July 1994; Accepted October 1994)

\begin{abstract}
$\square$ Abstract-Carp, Cyprinus carpio L, macrophages and neutrophilic granulocytes obtained from pronephros were cultured. Supernatant was harvested after $\mathbf{4 8} \mathrm{h}$ and tested for interleukin-1 (IL-1) bioactivity. A concentrationdependent stimulation of proliferation was found of carp $\mathrm{Ig}^{-}$lymphocytes as well as of the murine IL-1 dependent D10 (N4) M cell line. A $4 \mathrm{~h}$ treatment of cells with phorbol myristate acetate prior to culture gave a two- to fourfold enhancement of the bioactivity in the supernatant. Antibodies raised in sheep against human recombinant IL-1 $\alpha$ or IL-1 $\beta$ added to the supernatant annulled the Il-1 bioactivity. Western blot analysis of supernatants with sheep or rabbit polyclonal antisera against human Il-1s revealed $22 \mathrm{kDa}$ and $15 \mathrm{kDa}$ protein species. The predominant newly synthesized protein that was immunoprecipitated with these antisera was a $15 \mathrm{kDa}$ molecular species. We conclude that carp macrophages and neutrophilic granulocytes produce an IL-1-like molecule with $T$-cell proliferating potency that shares structural similarities with mammalian IL-1. This is the first evidence for the IL-1 signal protein in carp immunocompetent cells.
\end{abstract}

口Keywords-Fish immunology; Interleukin-1; Macrophages; Neutrophilic granulocytes.

Address correspondence to Dr. B. M. L. Verburg-van Kemenade, Department of Experimental Animal Morphology and Cell Biology, Agricultural University, P.O. Box 338, $6700 \mathrm{AH}$, Wageningen, The Netherlands.

\section{Introduction}

Interleukins play a pivotal role in regulating cellular interaction within the mammalian immune system $(1,2)$. Interleukin-1 (IL-1) is a pleiotropic paracrine and endocrine signalling molecule and is produced by a variety of cell types. Phagocytes are important sources for the synthesis and release of IL-1 for costimulation of $\mathrm{T}$-cell activation $(2,3)$. For fish, information on the immune response and its regulation is still fragmentary. In particular, the lack of specific markers for phenotyping the different cell (sub-)types of the immune system has hampered progress. However, evidence is accruing that also in fish interleukin-like molecules play an important role in generation and regulation of the immune response $(4,5)$. In trout, an interferon- $\gamma$ like molecule has been postulated as a macrophage activating factor $(6,7)$. An IL-2-like factor is secreted by carp leucocytes $(8,9)$. Until now only limited evidence for an IL-1-like factor in catfish (10) and salmon (11) has been presented. IL-1 was identified in man, mouse, rat, rabbit, sheep, pig, and cattle (12), IL-1-like activity has recently been described for birds (13), amphibians (14), fish $(4,5)$, tunicates (15), and echinoderms (16). Therefore IL- 1 is considered 
to be a phylogenetically well conserved molecule.

Here we address the question whether carp phagocytes influence $\mathrm{T}$ lymphocyte function through secretion of an IL-1like molecule. Fish phagocytes play a multifunctional role in immune regulation through phagocytosis, antigen presentation, and secretion of immunoregulators. The aim of this study was to identify possible activating signals of phagocytic cells towards $\mathrm{T}$ cells. We tested the secretion products of activated and non-activated macrophages and neutrophilic granulocytes for their effects on $\mathrm{T}$ lymphocyte proliferation, for activity in a bioassay with a murineIL-1-dependent indicator T-cell clone and for immuno-cross-reactivity with antibodies against recombinant human IL$1 \alpha$ and IL-1 $\beta$.

\section{Materials and Methods}

\section{Animals}

Common carp, Cyprinus carpio L., were obtained from laboratory stock ("De Haar Vissen", Agricultural University, Wageningen, the Netherlands). The fish were kept and reared at $23^{\circ} \mathrm{C}$ in recirculating, U.V. sterilized water and were fed daily pellet dry food (K30 Trouw, Putten, The Netherlands). Adult fish of 8-18 months, weighing around $200 \mathrm{~g}$ were used in all studies. The fish were anaesthetized in TMS (Tricaine Methane Sulfonate, Crescent Research Chemicals, Phoenix, USA); mixed arterial and venous blood was collected by puncture of the caudal vessels.

\section{Isolation of Carp Cells}

For the isolation procedure, only siliconized (Sigmacote, Sigma, Belgium) glass or plastic material was used. For cell isolation and culture, RPMI medium was used, which was adjusted to 270 mOsmol $\cdot \mathrm{kg}^{-1}$ by the addition of $\mathrm{H}_{2} \mathrm{O}$ (17). Cells were cultured at $26^{\circ} \mathrm{C}$ under $5 \% \mathrm{CO}_{2}$.

\section{Isolation of Peripheral \\ Blood Lymphocytes}

Freshly collected blood, diluted once with culture medium to which $50 \mathrm{IU} / \mathrm{mL}$ of heparin (Leo Pharmaceutical Products, Weesp, the Netherlands) had been added, was allowed to settle for $1 \mathrm{~h}$ at $4^{\circ} \mathrm{C}$. After centrifugation $(15 \mathrm{~min}$ at 300 $\times g$ with the brake disengaged), white cells were collected and layered on 1.5 volumes of Lymphoprep (density = $1.077 \mathrm{~g} / \mathrm{mL}$, Nycomed, Norway). Following 30 min centrifugation at $700 \times g$, the leucocyte layer was collected, washed three times and the final suspension adjusted to $10^{7}$ cells $/ \mathrm{mL}$. Adhering cells were removed by 90 min incubation at $26^{\circ} \mathrm{C}$, after seeding $1.0 \mathrm{~mL}$ aliquots into 24-well culture dishes (Corning, UK). Lymphocytes were then carefully collected and counted. Removal of the adhering phagocytic cells reduces in vitro lymphocyte proliferation by $60-80 \%$.

\section{Isolation and Stimulation of Pronephros Macrophages and Neutrophilic Granulocytes}

The pronephros, also referred to as "head kidney", comprises the major haematopoietic tissue in fish. Before dissection of pronephric tissue, blood was collected. Cell suspensions were prepared by passing the tissue through a $\mathbf{5 0}$ $\mu M$ nylon mesh. Cell suspensions were fractionated on a discontinuous Percoll density gradient as described before (17). A macrophage-enriched fraction (density range $1.02-1.07 \mathrm{~g} / \mathrm{cm}^{3}$ ), and a granulocyte-enriched fraction (density range $1.07-1.083 \mathrm{~g} / \mathrm{cm}^{3}$ ) were collected. The 
cells were washed and adjusted to a cell density of $10^{7}$ cells $/ \mathrm{mL}$. Next, cells were allowed to adhere for $1 \mathrm{~h}$ at a density of $10^{7}$ cells $/ \mathrm{mL}$ in polyethylene microtiter plates, either $1 \mathrm{~mL} /$ well in 24-well plates or $100 \mu \mathrm{L}$ in 96 -well plates. The supernatant and non-adhering cells were removed and the adhering cells, comprising $45 \pm 10 \%$ of the original suspension were washed three times with medium. This procedure finally yields a macrophage fraction containing $>60 \%$ macrophages with neutrophilic granulocytes as the second major cell type, and a neutrophilic granulocyte fraction which contains $>85 \%$ of neutrophilic granulocytes and macrophages as the second major cell type (17). Monolayers of macrophage-enriched fractions and neutrophilic granulocyte-enriched fractions were cultured in medium, supplemented with $0.5 \%(\mathrm{v} / \mathrm{v})$ pooled carp serum and penicillin-G (100.000 IU/mL, Sigma, USA), Streptomycin sulphate $(50 \mathrm{mg} / \mathrm{L}$, Serva, Germany) and L-glutamine (2.0 $\mathrm{mmol} / \mathrm{L})\left(\mathrm{RPMI}^{+}{ }^{+}\right)$. Cells were incubated for $48 \mathrm{~h}$. To stimulate cells with phorbol ester, $100 \mu \mathrm{g} / \mathrm{L}$ of phorbolmyristate-acetate (PMA; Sigma, USA) was added to the culture medium for $4 \mathrm{~h}$. Cells were subsequently washed three times with medium before the final culture period. Controls were treated similarly, but PMA was omitted. Activation of the cells was measured as respiratory burst activity, with a Nitroblue Tetrazolium reduction assay described in detail elsewhere (17).

\section{Bioassays}

Carp lymphocyte proliferation. Lymphocytes were cultured in 96-well plates in $200 \mu \mathrm{L} \mathrm{RPMI}^{++}$at a density of $5 \times 10^{6}$ cells $/ \mathrm{mL}$. Cells were stimulated to proliferate by applying a suboptimal concentration of $2 \mu \mathrm{g} / \mathrm{mL}$ phytohaemagglutinin (PHA; Difco, Detroit, USA) (8) for $4 \mathrm{~h}$, in $\mathrm{RPMI}^{++}$medium with $10^{-5} \mathrm{M}$ of $\beta$-mercaptoethanol. Next, an equal volume of the supernatants and culture medium was added, giving a final PHA concentration of $1 \mu \mathrm{g} / \mathrm{mL}$, and the culture was maintained for $72 \mathrm{~h}$. In other experiments, cells were stimulated to proliferate by a bidirectional mixed lymphocyte reaction (MLR) (18), with a culture period of $96 \mathrm{~h}$.

The activity of macrophage or granulocyte culture supernatants on lymphocyte proliferation was tested in the range of $0-20 \% \mathrm{v} / \mathrm{v}$ supernatant: $\mathrm{RPMI}^{++}$.

Cells cultured as described above were labelled with $185 \mathrm{KBq} / \mathrm{mL}{ }^{3} \mathrm{H}$ methyl thymidine (Amersham, UK) for $16 \mathrm{~h}$. The content of each well was harvested with a Skatron semi-automatic cell harvester (Lier, Norway). Next, the filters with retained cells were dried for 1 $h$ at $50^{\circ} \mathrm{C}$ and the filters were counted in a Beckman LS 1701 scintillation counter using Beckman Ready Safe Scintillation Fluid.

IL-1 bioassay. Il-1 bioactivity was measured using a subline of a cloned murine T-cell line D10.G4.1, designated D10 (N4) M (D10N) (19), optimized for enhanced reproducibility (20). Supernatants were serially diluted and assayed in triplicate. Recombinant human IL-1 $\beta$ (rIL-1 $\beta$, Biogen, Geneva, Switzerland) served as standard control. The detection limit was $\pm 0.1 \mathrm{U} / \mathrm{mL}$.

\section{Immunoblocking of IL-I-like Bioactivity}

Carp lymphocyte proliferation. The immunoglobulins in $30 \mu \mathrm{L}$ sheep antihuman-rIL- $1 \alpha$ and rIL-1 $\beta$ polyclonal sera (21), kindly provided by Dr. S. Poole, Nat. Inst. for Biol. Standards and Control, South Mimms, UK., were purified with a Protein A-Affi-gel MAPS II kit (Biorad, USA). After desalting (Biorad PD-10 column), the samples were freeze-dried and redissolved in $1.5 \mathrm{~mL}$ 
$\mathrm{H}_{2} \mathrm{O}$. Macrophage supernatants were incubated overnight at $4^{\circ} \mathrm{C}$ with a further $1: 1$ dilution of the purified antibodies to rIL- $1 \alpha$ and rIL- $1 \beta$ and the bioactivity assessed with the lymphocyte proliferation assay after suboptimal stimulation of the cells with PHA.

$I L-1$ bioassay. Prior to addition of the D10.G4.1 cells, culture supernatant samples were preincubated for $45 \mathrm{~min}$ at $37^{\circ} \mathrm{C}$ under $5 \% \mathrm{CO}_{2}$ with sheep anti-rIL $\alpha$ and/or anti-rIL-1 $\beta$ or goat anti-humanrIL- $1 \alpha$ and/or anti-rIL-1 $\beta$ (Glaxo, Geneva, Switzerland).

\section{Immunocharacterization of IL-1-Like Molecules}

Western blot analysis. Macrophage or granulocyte culture supernatants were dialysed overnight against 1/100 PBS and subsequently concentrated $10 \times$ in a Speedvac. Then $5 \mu \mathrm{L}$ of concentrate was run on a $12 \%$ Laemmli gel $(2 \mathrm{~h}, 100 \mathrm{~V})$. Gels were stained for total protein with a silverstain or Amido Black stain. Proteins were blotted for $1 \mathrm{~h}$ at $100 \mathrm{~V}$, or overnight at $20 \mathrm{~V}$, onto a nitrocellulose membrane. Blots were blocked for $2.4 \mathrm{~h}$ in Tris-buffered saline (TBS) containing $0.1 \%$ Tween 20 (Merck, Germany) and $1 \%$ bovine serum albumin (BSA). As primary antibody, polyclonal serum to human rIL- $1 \alpha$ and rIL-1 $\beta$, raised in sheep (21) or rabbit (kindly provided by Dr. S. Gillis, Immunex Res. and Dev. Corp., Washington, USA) were used. The secondary antibodies were rabbit-anti-sheep Ig and goat-anti-rabbit Ig (Dako, Denmark), conjugated with horse radish peroxidase. Antibody incubations $(1: 1000$ dilution) were carried out for $1.5 \mathrm{~h}$ at room temperature. After antibody incubations the blots were washed 3 times 10 min in TBS with $0.1 \%$ Tween-20; the peroxidase activity was visualized with 3,3 diaminobenzidine-tetrachloride as DAB, grade II chromogen (Sigma, USA).
Immunoenzymometric assay. For the immunoenzymometric assay, the Immunotech (Marseille, France) assay kit was chosen, which uses a monoclonal antibody raised to recombinant human IL-1 $\alpha$ and detection through conjugation of the second antibody with acetylcholineesterase. The range of the assay is $5-1000 \mathrm{pg} / \mathrm{mL}$.

\section{De novo Synthesis of \\ IL-1-Like Molecules}

Isolated macrophages $\left(0.5 \times 10^{7}\right.$ cells $/$ well) were prestimulated for $2 \mathrm{~h}$ with 10 ng/mL PMA. The cells were subsequently washed three times with a Hanks' balanced salt solution (HBSS; $270 \mathrm{mOsmol} / \mathrm{kg}$ ) without amino acids and subsequently labelled for $2 \mathrm{~h}$ with $250 \mu \mathrm{L}$ HBSS containing Tran ${ }^{35} \mathrm{~S}$-label ${ }^{\mathrm{TM}}(16.72$ $\mathrm{MBq} / \mathrm{mL}$; ICN, Belgium). The label was then carefully aspirated and, after three washes with HBSS, replaced by $\mathrm{RPMI}^{+}(400 \mu \mathrm{L} /$ well $)$ for $8 \mathrm{~h}$. Cells were collected in $500 \mu \mathrm{L} 50 \mathrm{mmol} / \mathrm{L}$ acetic acid and sonicated. After centrifugation $(10 \mathrm{~min}, 9000 \times \mathrm{g})$ the supernatant was lyophilized. The lyophilized material was redissolved in water and processed for immunoprecipitation with sheep-anti-IL- $1 \alpha$ and anti-IL-1 $\beta$, according to the method of Anderson and Blobel (22). Newly synthesized, immunoprecipitated material was separated by SDS-polyacrylamide gel electrophoresis and visualized by autoradiography of the dried gels using preflashed Kodak XAR-5 X-ray film. Autoradiographs were scanned densitometrically with a scanning densitometer (Gelscan XL, Pharmacia-LKB).

\section{Results}

A significant, dose-dependent costimulation of PHA induced lymphocyte proliferation was obtained by supple- 
mentation with $48 \mathrm{~h}$ culture supernatants of the macrophage- (data not shown) or neutrophilic granulocyte (Fig. 1) cell fractions. Maximum stimulation was observed with around $10 \%$ of culture supernatant from both cell types. Increasing the percentage of culture supernatant above $20 \%$, and up to $50 \%$, resulted in a 10-25\% decline of stimulation (data not shown). The interassay variation resulted from two sources, being the bioactivity of the supernatants and the proliferating activity of the isolated lymphocytes. A $4 \mathrm{~h}$ PMA pre-stimulation of macrophages or neutrophilic granulocytes consistently induced higher bioactivity in the culture supernatants (All data pooled, $p<0.005, n=50$ ). When macrophage and neutrophilic granulocyte supernatants were compared, macrophage supernatants were slightly $( \pm 10 \%)$, but significantly $(p<0.005)$ more effective in inducing lymphocyte proliferation. Also in the two-way MLR assay, as shown in Figure 2, addition of macrophage supernatant resulted in a

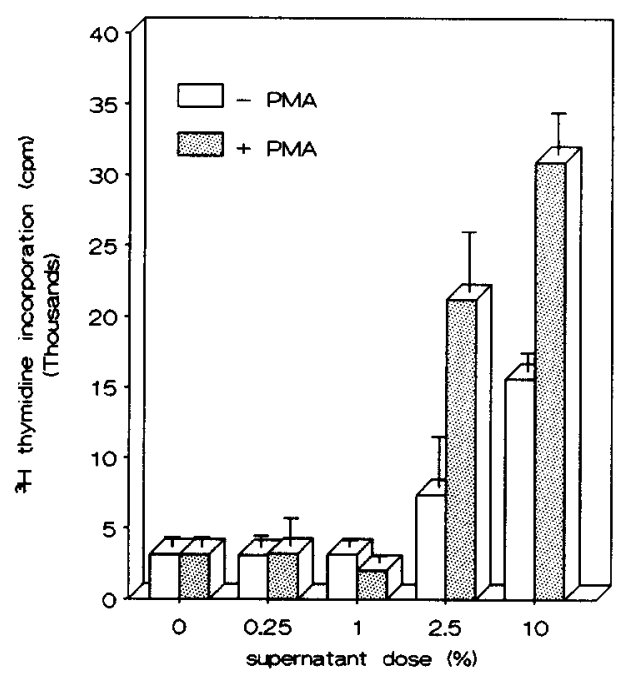

Figure 1. Effect of increasing doses of culture supernatants from non-stimulated-(-PMA) and pre-stimulated (4 h, $0.1 \mu \mathrm{g} / \mathrm{mL}$ PMA) (+PMA) neutrophilic granulocytes enriched fractions on ${ }^{3} \mathrm{H}$ thymidine incorporation by carp lymphocytes stimulated with PHA. Values are presented as means $\pm S D$ from three individual wells within the experiment. concentration-dependent increase of ${ }^{3} \mathrm{H}$ thymidine incorporation. The reduction in ${ }^{3} \mathrm{H}$ thymidine incorporation seen after removal of accessory cells were completely restored by addition of the supernatant.

The macrophage- and granulocyte culture supernatants were subsequently tested in the IL-1 specific D10 (N) bioassay. With both supernatants a significant and dose-dependent stimulation of ${ }^{3} \mathrm{H}$ thymidine incorporation was obtained. PMA stimulation of the macrophages and granulocytes resulted in a 7 to 8-fold increase of bioactivity in the supernatants as assessed with this assay (Fig. 3). Values for stimulation of ${ }^{3} \mathrm{H}$ thymidine incorporation by individual supernatants isolated from cells of different fish varied considerably and ranged from $12-170$ IU human $\mathrm{rIL}-1 \beta / \mathrm{mL}$ in supernatants from stimulated macrophages. The immunoenzymometric IL-1 $\alpha$ kit detected IL- $1 \alpha$ immunoreactivity in macrophage and granulocyte culture supernatants, equivalent to $6 \mathrm{pg}$ human IL-1 $\alpha$. However, recombinant human Il- $1 \alpha$ and human Il-1 $\beta$ in concentrations of $10-100$ $\mathrm{IU} / \mathrm{mL}$ were unable to induce ${ }^{3} \mathrm{H}$ thymidine uptake in carp lymphocytes (data not shown).

Pre-incubation of macrophage supernatant with protein A-purified sheep polyclonal antibodies against human rIl$1 \alpha$ and human rIl-1 $\beta$, completely abolished the proliferative response induced by control supernatants (Fig. 4a). The ${ }^{3} \mathrm{H}$ thymidine incorporation in the D10 $(\mathrm{N})$ IL-1 bioassay was also considerably blocked by both polyclonal goat-antihuman rIL- $1 \alpha$ and rIL- $1 \beta$ antibodies (Fig. 4b), and by the sheep rIL-1 $\alpha$ and sheep rIL-1 $\beta$ antibodies (Fig. $4 c$ ). In this assay IL-1 $\beta$ antibodies were most effective in blocking the proliferative response.

Western blot analysis of SDS-PAGE separated supernatant proteins with sheep- and rabbit- anti human rIL- $1 \alpha$ and $\beta$ sera revealed a major protein with an 


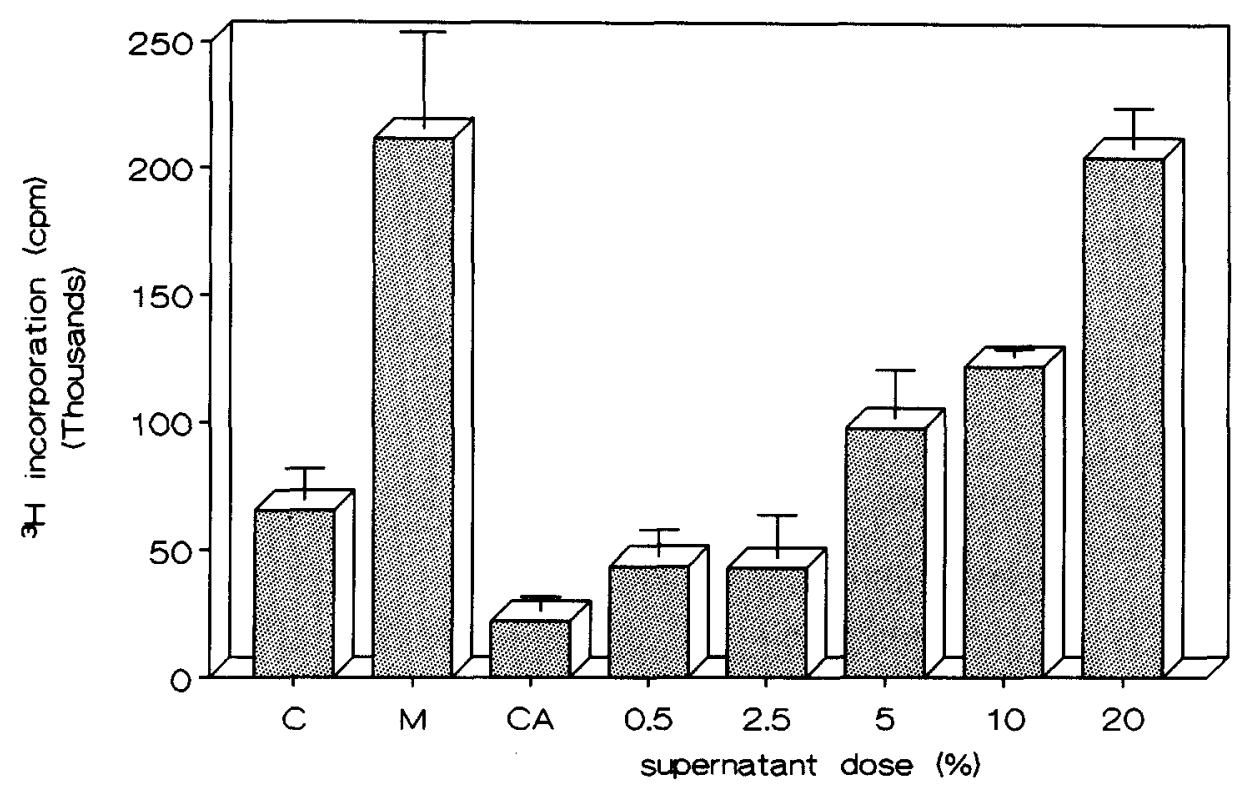

Figure 2. Enhancement of a two-way mixed-lymphocyte reaction by supplementation with culture supernatant of pre-stimulated macrophages. C: basic MLR reaction; $M$ : enhancement of the basic MLR reaction after supplementation with $10 \%$ supernatant; $C A$ : reduction of the MLR reaction after removal of accessory cells; supernatant doses: effect of increasing doses (v/v) of the macrophage culture supernatant on proliferation of the mixed lymphocytes after reduction of the number of accessory cells (CA). Values are given for ${ }^{3} \mathrm{H}$ thymidine incorporation in $\mathrm{cpm} \pm \mathrm{SD}$ from three wells. Basic values for the proliferation of cells from the individual fishes were: $445 \pm 424 \mathrm{cpm}$ and 2208 $\pm 861 \mathrm{cpm}$ for unstimulated cells; $2854 \pm 1535 \mathrm{cpm}$ and $7181 \pm 5400 \mathrm{cpm}$ after supplementation with $10 \%$ macrophage culture supernatant; and $166 \pm 65 \mathrm{cpm}$ and $377 \pm 86 \mathrm{cpm}$ after removal of accessory cells.

average $\mathrm{Mr}$ of $22.3 \mathrm{kDa}$ (range $21-24$ $\mathrm{kDa}, n=8$ ) for the rIL-1 $\alpha \mathrm{Ab}$ and 21.7 $\mathrm{kDa}$ (range $20-23, n=8$ ) for the rIL-1 $\beta$ Ab (Fig. 5). Next to these bands, a protein of approximately $15 \mathrm{kDa}$, (range 14$16 \mathrm{kDa}, n=4$ ) was detected with both antisera. With the rabbit anti-rHuman IL-1 also a weak band was detected at 32 $\mathrm{kDa}$ (range 31-33 kDa, $n=3$ ). Additionally, some molecular species with higher molecular weights were observed, derived from cross-reactivity of proteins in the pooled carp serum. The same crossreactivity is observed when normal sheep or rabbit sera are taken.

In de-novo synthesis studies with Tran ${ }^{35} \mathrm{~S}$-label and subsequent immunoprecipitation of radioactive proteins with sheep anti-rHuman IL- $1 \alpha$ and IL-1 $\beta$, one band was detected in the fraction of the cell lysate at a molecular weight of $15 \mathrm{kDa}$

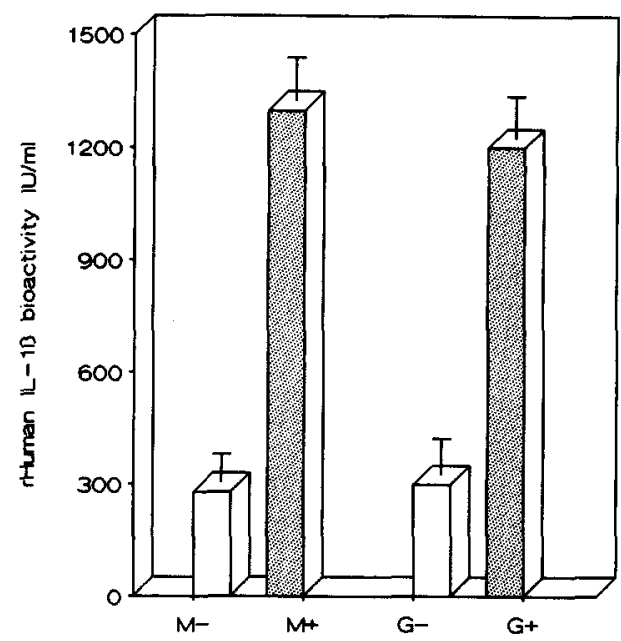

Figure 3. Bioactivity of the culture supernatants from non-stimulated $(-)$ and PMA-prestimulated (+) carp macrophage (M)- and neutrophilic granulocytes $(G)$ enriched cell populations, in stimulating proliferation of the IL-1dependent D10 (N4) M cells. $n=6$. 

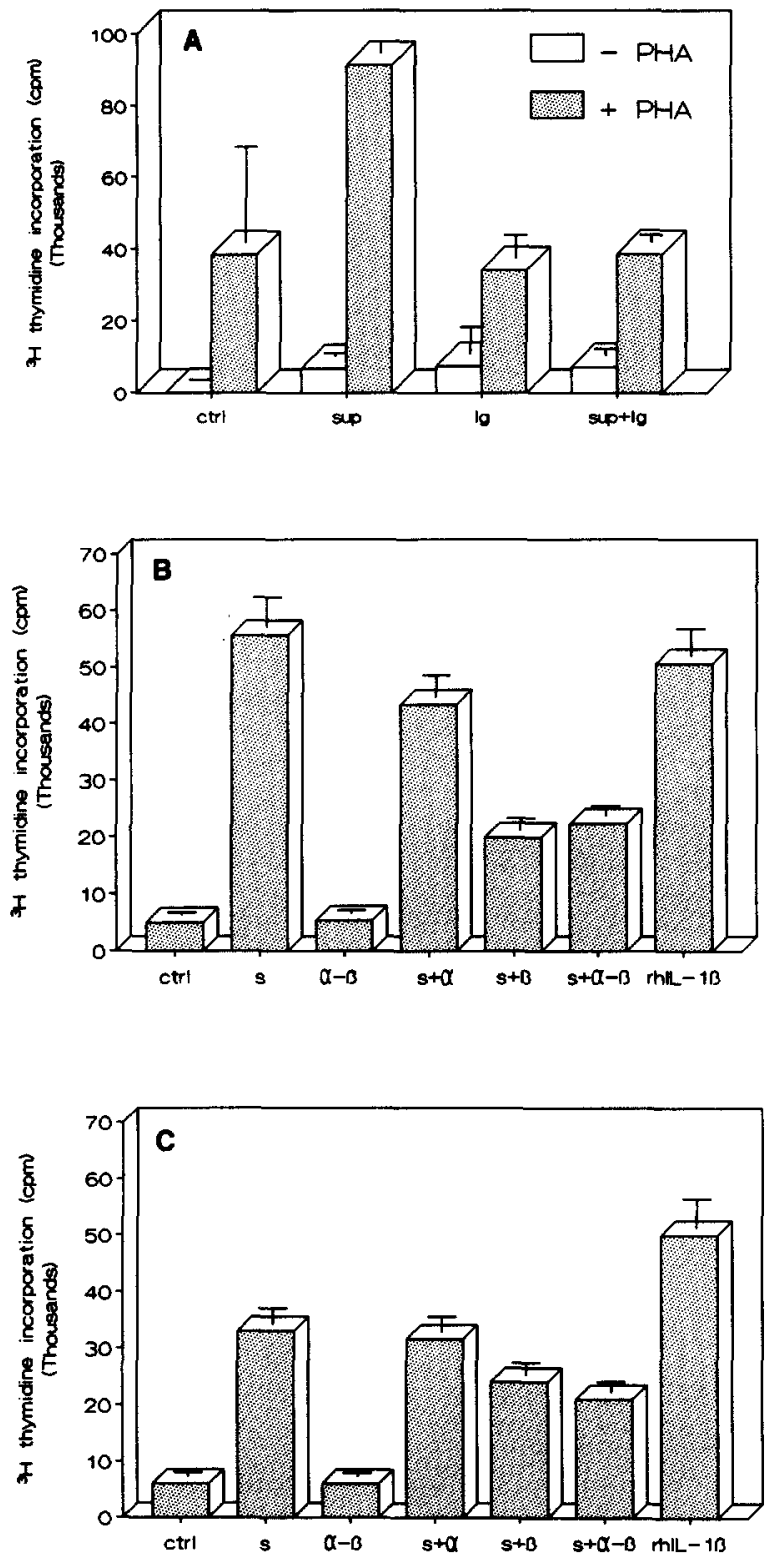

Flgure 4. (A) Immunoblocking by sheep-anti human rlL-1 $\alpha$ and $\beta$ IgGs $(1: 100)$ of the ${ }^{3} \mathrm{H}$-thymidine incorporation in non-stimulated (-PHA) or suboptimally stimulated (+PHA) carp lymphocytes induced by $10 \%$ supplementation with a supernatant of the macrophage-enriched cell fraction. Values are given as means $\pm S D$ from three individual wells. (B) Immunoblocking by goat-anti human rIL-1 $\alpha$ and $\beta(1: 5000)$ of the ${ }^{3} \mathrm{H}$-thymidine incorporation in D10 (N) cells induced by $5 \%$ supplementation with the supernatant of the macrophage-enriched cell fraction. Values are given as means \pm SD of three individual wells. (C) Immunoblocking by sheep-anti human rIL-1 $\alpha$ and $\beta(1: 300)$ of the ${ }^{3} \mathrm{H}$ thymidine incorporation in $\mathrm{D} 10(\mathrm{~N})$ cells, induced by $4 \%$ supplementation with supernatant of the macrophage-enriched cell fraction. Values are given as means \pm SD of three individual wells. ctrl: control; s: supplementation with culture supernatant; $\alpha-\beta$ : control with anti-IL-1 $\alpha$ and $\beta$ antibodies; $s+\alpha, s+\beta, s+\alpha-\beta$ : supplementation with culture supernatant, treated with anti-IL $-1 \alpha$ and/or $\beta$, rhlL-1 $\beta$ : $12.5 \mathrm{IU} / \mathrm{mL}$ recombinant IL-1 $\beta$. 

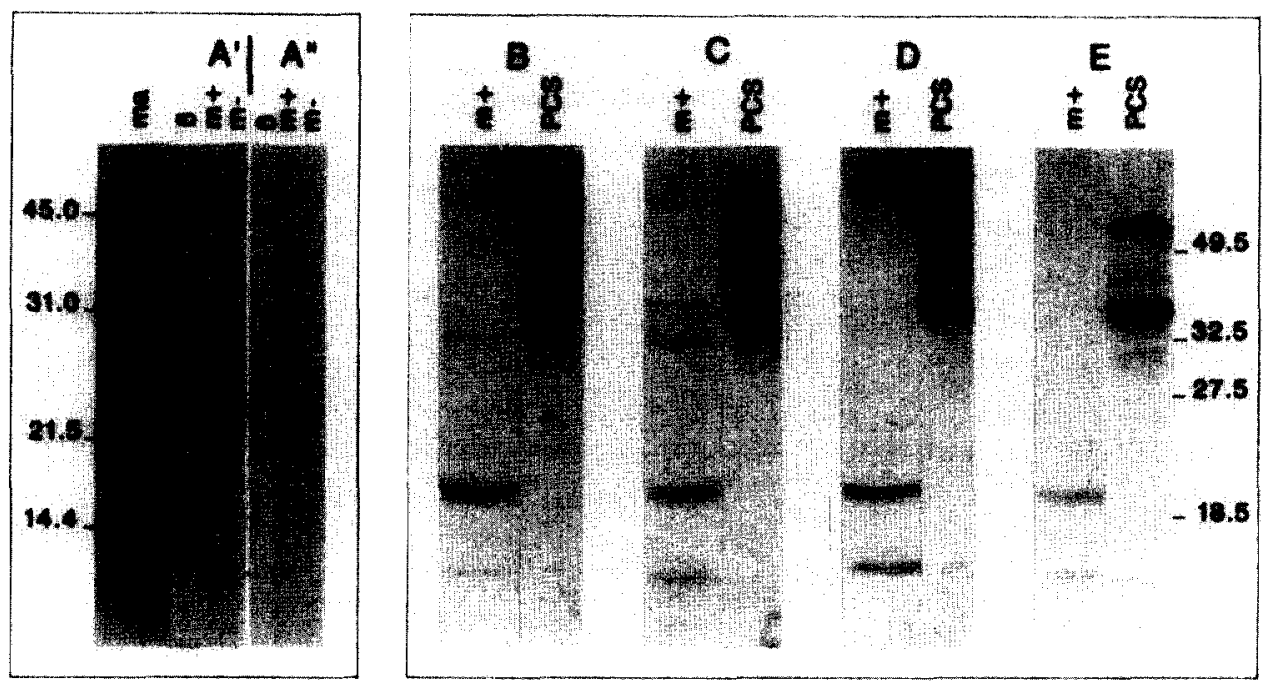

Figure 5. Western blot analysis with sheep- and rabbit-anti-rIL-1 $\alpha$ and $\beta$ (1:1000) of an SDS-PAGE gel of denatured proteins from $10 \times$ concentrated macrophage culture supernatants. ma: marker proteins, $m . w$. values $(\mathrm{kDa})$ are indicated in the figure; $\beta$ : human $\mathrm{rlL}-1 \beta$ reference; $m+:$ culture supernatant of pre-activated macrophages; $m-$ : culture supernatant of non-activated macrophages; PCS: $5 \%$ pooled carp serum in culture medium. $A^{\prime}$ shows the reaction of the rabbit antihuman $\mathrm{rIL}-1 \beta$ to the human IL-1 $\beta$ reference, and to a $10 \times$ concentrated macrophage culture supernatant. $A^{\prime \prime}$ shows the second antibody control of this reaction. $B, C, D$ and $E$ give the results of the incubation of macrophage culture supernatant and of pooled carp serum with respectively rabbit anti IL-1 $\alpha(B)$, rabbit anti IL-1 $\beta(C)$, sheep anti IL-1 $\alpha(D)$ and sheep anti IL-1 $\beta$ (E).

(range 14-16 kDa, $n=4$ ) (Fig. 6) and two faint ones at respectively $44 \mathrm{kDa}$ and $58 \mathrm{kDa}$. No newly synthesized immunoprecipitable radioactive peptides could be detected in the medium with these procedures.

\section{Discussion}

Carp macrophages and neutrophilic granulocytes produce and secrete a factor that stimulates lymphocyte proliferation in homologous (carp lymphocyte) as well as heterologous (mouse lymphocyte) bioassays. The strict IL-1-dependence of the latter assay and the quenching of bioactivity in supernatants by antibodies raised against human recombinant IL- $1 \alpha$ and IL-1 $\beta$ lead us to conclude that this factor is related to IL-1.

One could argue that in our proliferation assays with fish lymphocytes, both $T$ and $B$ cells were present, and therefore $T$-cell specificity of the assay is not granted. Previous studies, however, have demonstrated that PHA and ConA are selective stimulators of the $\mathrm{Ig}^{-}$lymphocyte population, and may thus be considered as a T-cell specific mitogen for fish lymphocytes $(23,24,25)$. Also the proliferation response to allogenic lymphocytes in fish, is considered to be T-cell-dependent (26). Therefore, we conclude that the factor present in our culture supernatants is indeed a T-cell proliferation factor. Removal of accessory cells from the lymphocyte cell fraction greatly diminished both PHAinduced proliferation of lymphocytes and the MLR response, indicating an important role for the antigen presenting cells in this proliferative response. In fish, the importance of the antigen presenting cells for antigen processing and lymphocyte proliferation has been recently established $(26,27)$.

The D10 (N) murine T-cell line has extensively been studied for detection of 


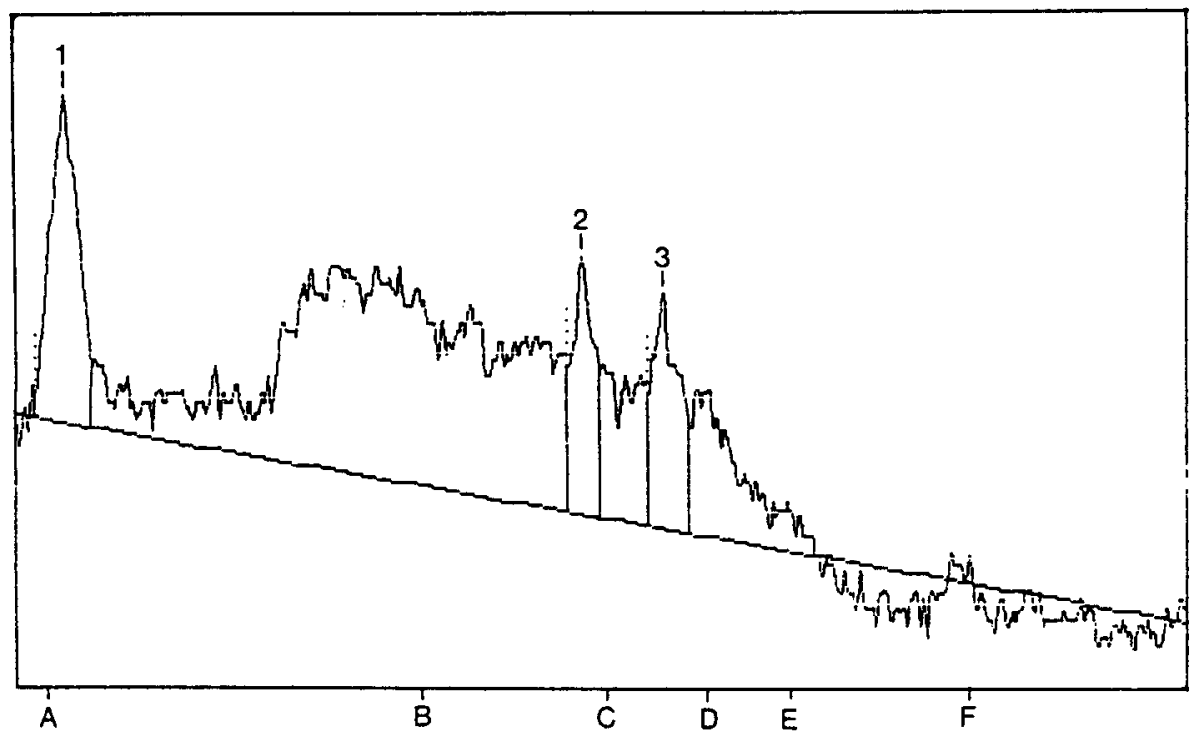

Figure 6. De novo synthesized, II-1 immunoreactive proteins in carp macrophages. $0.5 \times 10^{7}$ cells were $2 \mathrm{~h}$ pulse- $8 \mathrm{~h}$ chase incubated with $T r a n-{ }^{35} \mathrm{~S}$ label. Cell lysate was subsequently immunoprecipitated with sheep anti $\mathrm{rlL}-1 \alpha$ and $\mathrm{rIL}-1 \beta$ and analyzed on SDS-PAGE gel with autoradiogram scanning detection. Markers: A, 14 kDa; B, $30 \mathrm{kDa}$; C, $45 \mathrm{kDa}$; D, $69 \mathrm{kDa}$; E, $92 \mathrm{kDa} ; \mathrm{F}, 200 \mathrm{kDa}$. Molecular weight of the peaks: $1,15 \mathrm{kDa} ; 2,44 \mathrm{kDa} ; 3,58 \mathrm{kDa}$.

mammalian IL-1, and was shown to be specific for human or murine IL-1 (19). The $\mathrm{T}$-cell proliferating factor in the carp macrophage supernatants must therefore be related to mammalian IL-1. This argument is further strengthened by the blocking effect of anti-human rIL-1 antibodies. Yet, the failure of human IL- $1 \alpha$ or IL- $\beta$ to stimulate carp lymphocyte proliferation, indicates differences in bioactive structures. With the pulsechase experiments it could be demonstrated that at least the $15 \mathrm{kDa}$ immunoreactive peptide is newly synthesized by the cells in the macrophage fraction. While whole culture supernatants of macrophage and neutrophilic granulocyte cell populations were used, we cannot exclude the contribution of other ILlike factors in the stimulation of lymphocyte proliferation. For instance tumor necrosis factor (TNF), IL-8 and IL-6 are products of macrophage origin that may be co-stimulatory for fish lymphocyte proliferation (28). In mammals, prolifer- ation in the allogenic MLR response is greatly dependent on the presence of both IL-1 and gmCSF (29). To the best of our knowledge, reports on the presence of TNF-like, IL-8 and IL-6-like or gmCSF-like factors in fish are restricted to a positive reaction with IL-6 and $\mathrm{TNF} \alpha$ enzyme immunometric assays in sera from virus infected fish (30) and to colony stimulating activity in fish serum (31). Moreover, the sensitivity of trout macrophages to human TNF $\alpha$ also suggests a function of a TNF-like factor in fish (32).

The biphasic reaction in the doseresponse relationship for supernatants towards lymphocyte proliferation suggests that inhibitory factors are present in the supernatants. For mammals, IL-1 inhibitors, which under normal conditions function in tissue homeostasis, have been identified. These inhibitors may be produced by the interleukinsecreting cells or they may be serumderived factors (for review see 33). Dif- 
ferences in IL-1 bioactivity of individual supernatants is probably explained by a combination of macrophage activating or inhibiting factors in the culture medium and the above mentioned co-stimulatory or inhibitory factors for lymphocyte proliferation.

Western blot analysis with polyclonal anti-human rIL-1 antibodies revealed two clear bands with estimated apparent molecular weight values of $22 \mathrm{kDa}$ and $15 \mathrm{kDa}$ and a very weak one at $31 \mathrm{kDa}$. These values are strikingly similar to the values that have been reported for mammalian IL-1 precursor, intermediate, and end products of processing, and suggestive for conserved sequences (for review see 1). The $20-22 \mathrm{kDa}$ mammalian protein is generally considered to be a partially cleaved peptide $(34,35)$. Also a $22-$ kDa membrane-associated bioactive IL$1 \alpha$ peptide (36) has been reported, the presence of which is still a matter of debate (37). The mammalian IL-1 inhibitor protein that is interacting with both IL-1 receptors has an $\mathrm{Mr}$ of $22 \mathrm{kDa}$ (33). Cross reactivity, due to peptide homology, of putative fish IL-1 inhibitors with the polyclonal antibodies against IL-1, therefore cannot be excluded. The bands at high molecular weight values, noted with pooled carp serum, can probably be attributed to nonspecific interaction with high concentrations of serum proteins. This could be deduced from the fact that they could also be observed when normal sheep and normal rabbit serum were used.

Western blot analysis of catfish monocyte supernatants detected with the very same antisera used in this study revealed immunopositive bands at 60,43 , and 30 $\mathrm{kDa}$ for anti-IL-1 $\alpha$, and at 70 and 21 for anti-IL-1 $\beta$ (10). With antibodies to murine $I L-1 \alpha$ and $I L-1 \beta$, immunoreactive proteins were registered at $70,42,28$, and $12 \mathrm{kDa}(10)$. Only 65 and $70 \mathrm{kDa}$ proteins were reported to be bioactive in fish lymphocyte proliferation assays, whereas the smaller peptide $( \pm 14 \mathrm{kDa})$ is exclusively active in a mammalian bioassay. This conclusion is at variance with our findings, as also a G100 column chromatography separation (personal observation) indicated that the bioactivity was related to proteins smaller than $50 \mathrm{kDa}$.

\section{Perspectives}

The current findings, revealing an IL1-like molecule in carp phagocytes, substantiate the concept of a cytokine regulated, host defence response in carp. The importance of these cytokines is probably reflected in their conserved nature. However, although our knowledge of mammalian IL-1 activities is considerable and although sequences of different vertebrate IL-1 molecules have been resolved, the receptor binding sequences have not yet been elucidated. IL- $1 \alpha$ and IL- $1 \beta$, having only $26 \%$ sequence identity, occupy the same receptor. Sequence comparison of, e.g., rabbit, mouse, and human IL-1 sequences have revealed large interspecies differences. This complicates the elucidation of lower vertebrate and invertebrate IL-1 sequences through cross-hybridization studies. Positive detection of the IL-1 like bioactivity and immunoreactivity however prompted us to pursue further biochemical and molecular characterization of the carp IL-1 signal substance.

Acknowledgements-The authors wish to thank Erik van Engelen, Angelique van der Heyden, Richard Smith, Frans Gerbens, and Jolieta Eckhardt who contributed to this research as part of their Masters degree research projects. Dr. H. Savelkoul is acknowledged for his advice and stimulating discussions. Adrie Groeneveld provided skillful technical assistance and Wim Valen is thanked for the photographs. 


\section{References}

1. Dinarello, C. A. The biology of Interleukin-1. In: Kishimoto, T. Ed. Interleukins: molecular biology and immunology. Chem. Immunol. 51: 1-34; 1992.

2. Di Giovine, F. S.; Duff, G. W. IL-1: the first interleukin. Immunol. Today. 11:13-20; 1990.

3. Arai, K.; Lee, F.; Miyajima, A.; Miyatake, S.; Arai, N.; Yokota, T. Cytokines: coordinators of immune and inflammatory responses. Annu. Rev. Biochem. 59:783-836; 1990.

4. Secombes, C. J. The phylogeny of cytokines. In: Thomson, A. Ed. The cytokine handbook. London, UK: Academic Press; 1991:387-425.

5. Cohen, N.; Haynes, L. The phylogenic conservation of cytokines. In: Warr, G. W.; Cohen, N., Eds. Phylogenesis of immune functions. Boca Raton, FL: CRC Press; 1991:241-269.

6. Graham, S.; Secombes, C. J. The production of a macrophage-activating factor from rainbow trout Salmo gairdneri leucocytes. Immunology 65:293-297; 1988.

7. Graham, S.; Secombes, C. J. Do fish lymphocytes secrete interferon- $\gamma$. J Fish Biol. 36: 563-573; 1990.

8. Grondel, J. L.; Harmsen, E. G. M. Phylogeny of interleukins: growth factors produced by leucocytes of the cyprinid fish, Cyprinus carpio L. Immunology 52:477-482; 1984.

9. Caspi, R. R.; Avtalion, R. Evidence for the existence of an IL-2 like lymphocyte growth promoting factor in a bony fish, Cyprinus carpio L. Dev. Comp. Immunol. 8:51-60; 1984.

10. Elsaesser, C. F. Clem, L. W. Functionally distinct high and low molecular weight species of channel catfish and mouse IL-1. Cytokine 5: 10-20; 1994.

11. Hamby, B. A.; Huggins, E. M.; Lachman, L. B.; Dinarello, C. A.; Sigel, M. M. Fish lymphocytes respond to human IL-1. Lymphokine Res. 5:157-162; 1986.

12. Shaw, R. A. Molecular biology of cytokines. In: Thomson, A. Ed. The cytokine handbook. London, UK: Academic Press; 1991:19-46.

13. Hayari, Y.; Schauenstein, K.; Globerson, A. Avian lymphokines, 1I: Interleukin-1 activity in supernatants of stimulated adherent splenocytes of chickens. Dev. Comp. Immunol. 5: 785-789; 1982.

14. Watkins, D.; Parsons, S. C.; Cohen, N. A factor with interleukin-1-like activity is produced by peritoneal cells from the frog, Xenopus laevis. Immunology 62:669-673; 1987.

15. Beck, G.; Vasta, G. R.; Marchalonis, J. J.; Habicht, G. S. Characterization of interleukin-1 activity in tunicates. Comp. Biochem. Physiol. 92b:93-98; 1989.

16. Beck, G. ; Habicht, G. S. Isolation and characterization of a primitive IL-1 like protein from an invertebrate, Asterias forbesi. Proc. Natl. Acad. Sci. USA. 83:7429-7433; 1986.

17. Verburg-van Kemenade, B. M. L.; Groen- eveld, A.; van Rens, B. T. T. M.; Rombout, J. H. W. M. Characterization of macrophages and neutrophilic granulocytes from the pronephros of carp (Cyprinus carpio) $\mathbf{J}$. of Exp. Biol. 187:143-158; 1994.

18. Caspi, R. R.; Avtalion, R. R. The mixed lymphocyte reaction (MLR) in carp: Bidirectional and unidirectional MLR responses. Dev. Comp. Immunol. 8:631-637; 1984.

19. Hopkins, S. J.; Humphreys, M. Bioassay of interleukin- 1 in serum and plasma following removal of inhibitory activity with polyethylene glycol. J. Immunol. Methods. 120:271-276; 1989.

20. Debets, R.; Van Joost, T.; Benner, R.; Prens, E. P. Psoriatic epidermal cells release elevated levels of immunoreactive and biologically active interleukins 1 and 6: modulation of corticosteroid treatment. In: Schroot, B and Schaeffer, H. Eds. Pharmacology and the skin. 1993:158-166.

21. Poole, S.; Bristow, A. F.; Selfirk, S.; Rafferty, B. Development and application of radioimmunoassays for interleukin-1 $\alpha$ and interleukin- $1 \beta$. J. Immunol. Methods. 116:259-264; 1989.

22. Anderson, D. J.; Blobel, G. Immunoprecipitation of proteins from cell-free translations. Methods Enzymol. 6:111-121; 1983.

23. Caspi, R. R.; Shahrabani, R.; Kehati-Dan, T.; Avtalion, R. Heterogeneity of mitogenresponsive lymphocytes in carp (Cyprinus carpio). Dev. Comp. Immunol. 8:61-70; 1984.

24. Sizemore, R. C.; Miller, N. W.; Cuchens, M. A.; Lobb, C. J.; Clem, L. W. Phylogeny of lymphocyte heterogeneity: the cellular requirements for in vitro mitogenic responses of channel catfish leukocytes. J. Immunol. 133: 2920-2924; 1984.

25. Koumans- van Diepen, J. C. E.; Harmsen, E. G. M.; Rombout, J. H. W. M. Immunocytochemical analysis of mitogen responses of carp (Cyprinus carpio L.) peripheral blood leucocytes. Vet. Immunol. Immunopathol. 42: 209-219; 1994.

26. Miller, N. W.; Deuter, A.; Clem, L. W. Phylogeny of lymphocyte heterogeneity: the cellular requirements for the mixed leucocyte reaction with channel catfish. Immunology 59:123-128; 1986.

27. Vallejo, A. N.; Miller, N. W.; Clem, L. W. Cellular pathway(s) of antigen processing in fish APC: effect of varying in vitro temperatures on antigen catabolism. Dev. Comp. Immunol. 16: 367-381; 1992.

28. Holsti, M. A.; Raulet, D. H. IL-6 and IL-1 synergize to stimulate $\mathrm{IL}-2$ production and proliferation of peripheral T cells. J. of Immunol. 43:2514-2519; 1989.

29. Naito, K.; Inaba, K.; Hirayama, Y.; InabaMiyanaba, M.; Sudo, T.; Muramatsu, S. Macrophage factors which enhance the mixed leucocyte reaction initiated by dendritic cells. J. of Immunol. 142:1834-1839; 1989. 
30. Ahne, W. Presence of interleukins (IL-1, IL-3, IL-6) and the tumor necrosis factor (TNF alpha) in fish sera. Bull. Eur. Ass. Fish Pathol. 13:106-107; 1993.

31. Kodama, H.; Mukamoto, M.; Baba, T.; Mule, D. Macrophage-colony stimulating activity in rainbow trout (Oncorhynchus mykiss) serum. Modulators of Fish Immune Resp. 1:59-66; 1994.

32. Hardie, L. J.; Chappell, L. H.; Secombes, C. J. Human tumor necrosis factor $\alpha$ influences rainbow trout Oncorhynchus mykiss leucocyte responses. Vet. Immunol. Immunopathol. 40:73-84; 1994.

33. Dinarello, C. A.; Thomson, R. C. Blocking IL-1: interleukin 1 receptor antagonist in vivo and in vitro. Immunol. Today. 12:404-411; 1991.
34. Beuscher, H. U.; Guenther, C.; Roellinghoff, M. IL-1 $\beta$ is secreted by activated murine macrophages as biologically inactive precursor. J. Immunol. 144:2179-2183; 1990.

35. Auron, P. E.; Warner, S. J.; Webb, A. C.; Cannon, J. G.; Bernheim, H. A.; McAdam, K. J.; Rosenwasser, L. J.; LoPreste, G.; Mucci, S. F.; Dinarello, C. A. Studies on the molecular nature of human interleukin 1. J. Biol. Chem. 138:1447-1456; 1987.

36. Brody, D. T.; Durum, S. K. Membrane IL-1: IL- $1 \alpha$ precursor binds to the plasma membrane via a lectine-like interaction. J. Immunol. 143: 1183-1187; 1989.

37. Minnich-Carruth, L. L.; Suttles, J.; Mizel, $\mathrm{S}$. B. Evidence against the existence of a membrane form of murine IL-1 $\alpha$. J. Immunol. 142: 526-530; 1989. 